How to cite: Angew. Chem. Int. Ed. 2021, 60, 17952-17956

Solid-State Batteries

International Edition:

doi.org/10.1002/anie.202106018

German Edition:

doi.org/10.1002/ange.202106018

\title{
Influence of Iron Sulfide Nanoparticle Sizes in Solid-State Batteries**
}

\author{
Georg F. Dewald, Zainab Liaqat, Martin Alexander Lange, Wolfgang Tremel,* and \\ Wolfgang G. Zeier*
}

\begin{abstract}
Given the inherent performance limitations of intercalation-based lithium-ion batteries, solid-state conversion batteries are promising systems for future energy storage. A high specific capacity and natural abundancy make iron disulfide $\left(\mathrm{FeS}_{2}\right)$ a promising cathode-active material. In this work, $\mathrm{FeS}_{2}$ nanoparticles were prepared solvothermally. By adjusting the synthesis conditions, samples with average particle diameters between $10 \mathrm{~nm}$ and $35 \mathrm{~nm}$ were synthesized. The electrochemical performance was evaluated in solid-state cells with a Li-argyrodite solid electrolyte. While the reduction of $\mathrm{FeS}_{2}$ was found to be irreversible in the initial discharge, a stable cycling of the reduced species was observed subsequently. A positive effect of smaller particle dimensions on $\mathrm{FeS}_{2}$ utilization was identified, which can be attributed to a higher interfacial contact area and shortened diffusion pathways inside the $\mathrm{FeS}_{2}$ particles. These results highlight the general importance of morphological design to exploit the promising theoretical capacity of conversion electrodes in solid-state batteries.
\end{abstract}

I ron disulfide $\mathrm{FeS}_{2}$ has been explored as a high-energy, abundant and environmentally friendly material for electrochemical energy storage. ${ }^{[1-3]}$ While Li-FeS 2 primary batteries are commercially available, the poor reversibility has limited the application of rechargeable cells. Compared to intercalation-type active materials, conversion reactions of transition

[*] Dr. G. F. Dewald

Institute of Physical Chemistry, Justus-Liebig-University Giessen Heinrich-Buff-Ring 17, 35392 Giessen (Germany)

Z. Liaqat, M. A. Lange, Prof. Dr. W. Tremel

Chemistry Department, Johannes Gutenberg University

Duesbergweg 10-14, 55128 Mainz (Germany)

E-mail: tremel@uni-mainz.de

Prof. Dr. W. G. Zeier

Institute of Inorganic and Analytical Chemistry, University of Münster

Corrensstrasse 30, 48149 Münster (Germany)

and

Helmholtz Insitut Münster, FZ Jülich

Corensstrasse 46, 48149 Münster (Germany)

E-mail:wzeier@uni-muenster.de

[**: A previous version of this manuscript has been deposited on a preprint server (https://doi.org/10.26434/chemrxiv.14483370).

(-) Supporting information and the ORCID identification number(s) for

(iD) the the author(s) of this article can be found under: https://doi.org/10.1002/anie.202106018.

of (c) 2021 The Authors. Angewandte Chemie International Edition published by Wiley-VCH GmbH. This is an open access article under the terms of the Creative Commons Attribution Non-Commercial License, which permits use, distribution and reproduction in any medium, provided the original work is properly cited and is not used for commercial purposes. metal sulfides often suffer from limited reversibility due to sluggish kinetics, detrimental volume changes and the often insulating character of reaction products. ${ }^{[4-6]}$ With the goal of enabling the reversible four-electron energy storage in $\mathrm{FeS}_{2}$ based cathodes nanostructuring of active materials seems promising. ${ }^{[7,8]}$ In $\mathrm{Li}^{-} \mathrm{FeS}_{2}$ cells, the influence of the $\mathrm{FeS}_{2}$ crystallite size on the cell performance has been studied in the past with both liquid and solid electrolytes as slow lithium diffusion within $\mathrm{FeS}_{2}$ results in kinetic limitations. ${ }^{[9-11]} \mathrm{By}$ improving the reaction kinetics and lowering the needed $\mathrm{Li}^{+}$ diffusion pathways with reduced particle sizes, the reversibility and rate capability has been improved. ${ }^{[12,13]}$

Nevertheless, similar to Li-S batteries, the detrimental dissolution of polysulfides is possible in $\mathrm{Li}-\mathrm{FeS}_{2}$ batteries, ${ }^{[14,15]}$ and a potential mitigation strategy could be the use in solidstate batteries. ${ }^{[16]}$ Whereas sulfide-based solid electrolytes suffer from oxidative decomposition in contact to highvoltage intercalation electrodes, the lower redox potential of $\mathrm{FeS}_{2}$ possibly better agrees with the oxidative stability limit of thiophosphates. ${ }^{[17-19]}$ This constitutes an additional advantage for using $\mathrm{FeS}_{2}$ as a cathode active material.

Thus, inspired by the promising option of tailoring the particle sizes of $\mathrm{FeS}_{2}$ and their potential use in solid-state batteries, in this work we prepared $\mathrm{FeS}_{2}$ nanoparticles with various size distributions and characterized their electrochemical performance in solid-state batteries. Reduced $\mathrm{FeS}_{2}$ nanoparticle sizes showed a positive impact on the total capacity and rate capability, highlighting the potential of nanosized $\mathrm{FeS}_{2}$ as cathode active conversion material in solidstate batteries.

The $\mathrm{FeS}_{2}$ nanoparticles were prepared solvothermally and all experimental details can be found in the Supporting Information. Figure 1 a shows the X-ray diffraction patterns of the as-obtained $\mathrm{FeS}_{2}$ samples in which all intensities can be assigned to cubic $\mathrm{FeS}_{2}$ without detectable crystalline impurities. By varying the ratio of oleic acid (OAc) to oleylamin (OAm), denoted as OAc:OAm, different particle size distributions were obtained. The different average particle sizes are evaluated using a Pawley fit (see Supporting Information), ${ }^{[20]}$ and three different average particle sizes of $11( \pm 0.3) \mathrm{nm}, 33( \pm 0.3) \mathrm{nm}$ and $36( \pm 0.5) \mathrm{nm}$ are found. Transmission electron microscopy (TEM) was used to evaluate the particle size distribution (Figure 1 b,c). For reasonable statistics, around 100 particles of a representative sample section were analyzed. Particle diameters were calculated by assuming an ideal spherical particle shape based on the measured area. For the $\mathrm{FeS}_{2}$ samples in this study, a decreased OAc:OAm ratio was found to result in reduced particles sized. Consequently, the smallest particles in the range of 5$15 \mathrm{~nm}$ were found for an OAc:OAm ratio of 1:2. Overall, average particle sizes of $9.7( \pm 1.3) \mathrm{nm}, 22.1( \pm 1.5) \mathrm{nm}$ and 
(a)

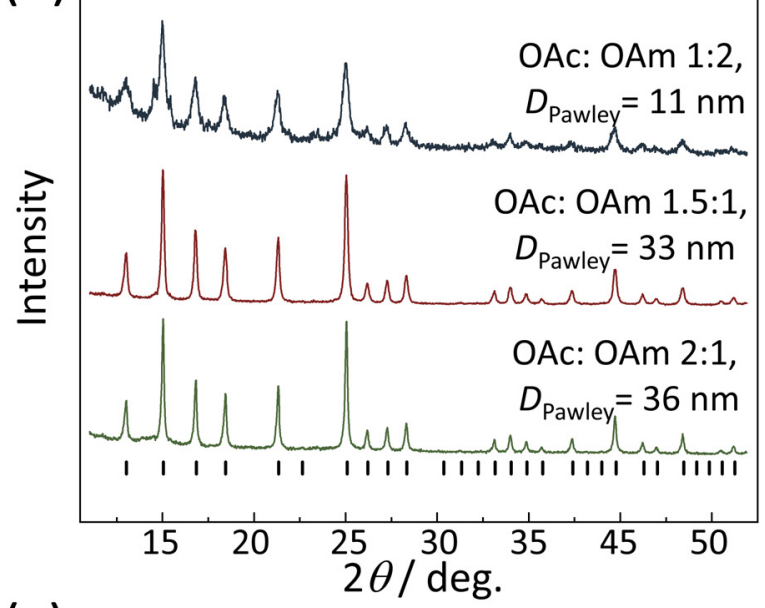

(c)

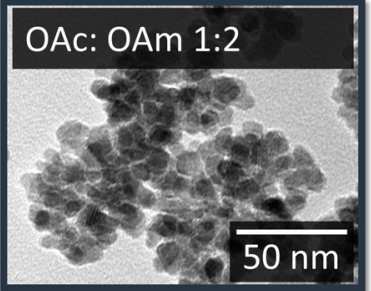

(b)
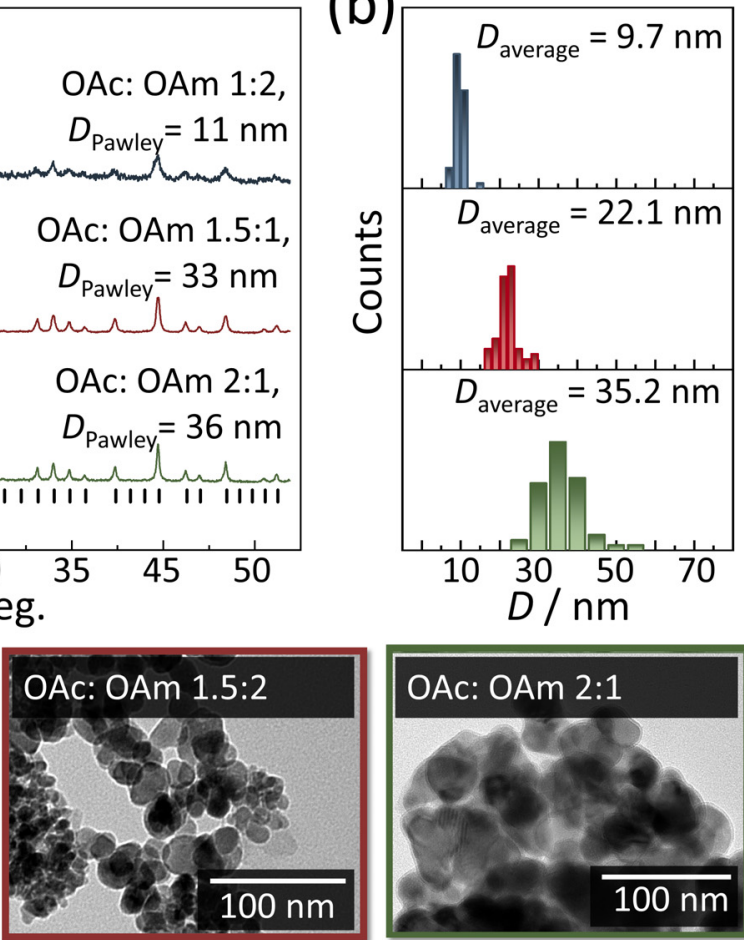

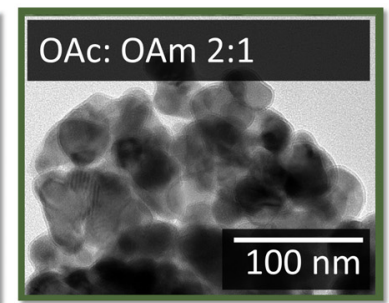

Figure 1. (a) X-ray diffractograms of $\mathrm{FeS}_{2}$ nanoparticles from solvothermal reactions as a function of oleic acid (OAc): oleylamine (OAm) ratios: 1:2 (blue), 1.5:1 (red) and 2:1 (green), recorded with Mo $\mathrm{K}_{\alpha}$ radiation. Average particle sizes are estimated and shown as insets based on Pawley fitting. (b) Particle size distributions of as-synthesized $\mathrm{FeS}_{2}$ particles from TEM imaging. (c) TEM images of the assynthesized $\mathrm{FeS}_{2}$ particles. For an OAc:OAm ratio of 1:2, particle sizes were in the range of 5-15 nm, OAc:OAm ratios of 1.5:1 and 2:1 resulted in larger particles.

$35.2( \pm 4.9) \mathrm{nm}$ are found via TEM, which corroborate the sizes obtained from $\mathrm{X}$-ray diffraction.

Solid-state $\mathrm{In} / \mathrm{InLi}\left|\mathrm{Li}_{6} \mathrm{PS}_{5} \mathrm{Cl}\right| \mathrm{FeS}_{2}-\mathrm{Li}_{6} \mathrm{PS}_{5} \mathrm{Cl}-\mathrm{C}$ cells were assembled to evaluate the influence of the $\mathrm{FeS}_{2}$ nanoparticle sizes on the resulting electrochemical properties. Cathodes were prepared with a $\mathrm{FeS}_{2}$ loading of $3.8 \mathrm{mg} \mathrm{cm}^{-2}$. In order to ensure sufficient ionic and electronic charge transport within
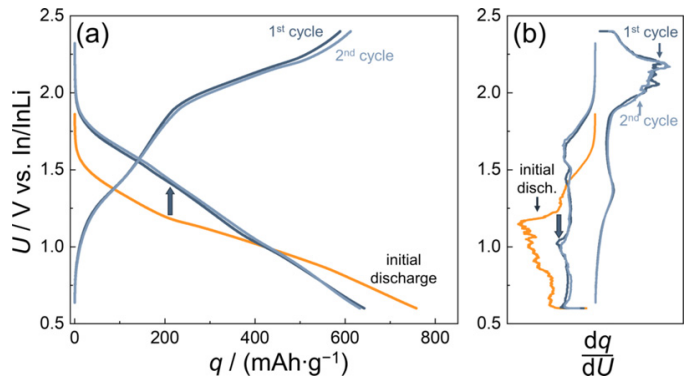

Figure 2. Typical potential profiles of initial discharge (orange) and the subsequent cycles (blue) of $\operatorname{InLi} / \mathrm{Li}_{6} \mathrm{PS}_{5} \mathrm{Cl} / \mathrm{FeS}_{2}-\mathrm{C}-\mathrm{Li}_{6} \mathrm{PS}_{5} \mathrm{Cl}$ cell with an average $\mathrm{FeS}_{2}$ particle size $\bar{D}$ of $9.7 \mathrm{~nm}$. The initial discharge is characterized by two slopes and a high capacity of $760 \mathrm{mAh}^{-1}$. Two processes are observed for the following charging. However, the subsequent discharge steps differ significantly from the initial reduction of $\mathrm{FeS}_{2}$. Besides cycling of $\mathrm{FeS}_{2}$ and associated phases, reductive/ oxidative decomposition of $\mathrm{Li}_{6} \mathrm{PS}_{5} \mathrm{Cl}$ and cycling of decomposed phases are expected in this potential range.

the cathodes, high volume fractions of carbon and solid electrolyte $\quad(23 \mathrm{vol} \% \quad \mathrm{C}, \quad 63 \mathrm{vol} \%$ $\left.\mathrm{Li}_{6} \mathrm{PS}_{5} \mathrm{Cl}\right)$ were employed. ${ }^{[21]}$ Unlike conventional layered oxide cathode materials, $\mathrm{FeS}_{2}$ is discharged in the initial cyclization step. The subsequent charge-discharge cycle is defined as first cycle in the following.

Figure 2 shows the potential profile for the initial discharge and the following charge-discharge cycles of an exemplary cell. The initial discharge differs from the subsequent steps. During the initial discharge, two slopes indicate that different reduction reactions are occurring. Accordingly, two slopes are observed in the following first charge. Importantly, the high initial discharge capacity of $760 \mathrm{mAhg}^{-1}$ cannot be recovered during charging. Comparing initial and first discharge, the latter is characterized by significantly higher potentials and a lower overall capacity. Based on this complex behavior, the underlying cell reactions are likely highly convoluted. The overall four-electron reduction of $\mathrm{FeS}_{2}$ during the initial discharge is typically described by [Eq. (1)]

$\mathrm{FeS}_{2}+4 \mathrm{Li}^{+}+4 \mathrm{e}^{-} \rightarrow 2 \mathrm{Li}_{2} \mathrm{~S}+\mathrm{Fe}$

corresponding to a theoretical specific capacity of $894 \mathrm{mAhg}^{-1}$. As the initial discharge capacity is close to this value, contributions of both $\mathrm{Fe}^{+\mathrm{II}}$ and $\mathrm{S}^{\mathrm{I}}$ reduction are expected here. Commonly, a two-step reaction via reduction of $\mathrm{FeS}_{2}$ to $\mathrm{Li}_{2} \mathrm{FeS}_{2}$, followed by reduction to $\mathrm{Fe}^{0}$ and $\mathrm{Li}_{2} \mathrm{~S}$, is assumed. ${ }^{[22,23]}$ During charging, the formation of multiple electrochemically active species, for instance $\mathrm{S}, \mathrm{FeS}_{y}$ and $\mathrm{Li}_{x} \mathrm{FeS}_{2}$, was reported before and may be at play here, especially since the significant difference between initial and first discharge is observed. ${ }^{[24,25]}$ Yersak et al. attributed the irreversibility of the initial discharge to the formation of orthorhombic $\mathrm{FeS}_{2}$ during the first charge,${ }^{[9]}$ but formation of $\mathrm{Fe}^{0}$ can also be expected to lead to irreversibility. Additionally, volume changes of the active material during cycling need to be considered together with chemomechanical degradation. ${ }^{[26]}$ Furthermore, reductive decomposition of the electrolyte $\mathrm{Li}_{6} \mathrm{PS}_{5} \mathrm{Cl}$ may be expected during the initial discharge, ${ }^{[18,27]}$ and a certain additional capacity from the solid electrolyte seems possible. ${ }^{[19]}$ However, the decomposition of the solid electrolyte seems negligible, considering the minor changes in the X-ray photoemission spectra (see below). Consequently, the irreversible capacity of the initial discharge 
is most likely caused by a superposition of the partial irreversible reduction of $\mathrm{FeS}_{2}$, electrochemical electrolyte degradation and chemomechanical losses. Overall, a resulting complex mixture of multiple redox-active species during the initial discharge and the following charge seems to occur in $\mathrm{FeS}_{2}$ based solid state batteries.

By comparing the electrochemical performance of $\mathrm{FeS}_{2}$ $\mathrm{Li}_{6} \mathrm{PS}_{5} \mathrm{Cl}$ cathodes, the influence of $\mathrm{FeS}_{2}$ particle size on the electrochemical utilization is highlighted (Figure 3). While the potential profiles show similar characteristics for all investigated samples, the overall capacity as well as the performance at higher cycling rates is improved by reduced particle sizes, despite the slightly higher overall cell resistances (see Supporting Information S5). Within the investigated period of 40 cycles, continuous capacity fading is observed, which is stressed for the sample with the smallest particles. This trend can possibly be explained by the higher interfacial area between $\mathrm{FeS}_{2}$ and conducting cathode matrix for smaller particles.

In order to elucidate the underlying processes and differences of different particle sizes during cyclization in $\mathrm{FeS}_{2}-\mathrm{C}$ $\mathrm{Li}_{6} \mathrm{PS}_{5} \mathrm{Cl}$ cathode composites, the composites were character-

(a)

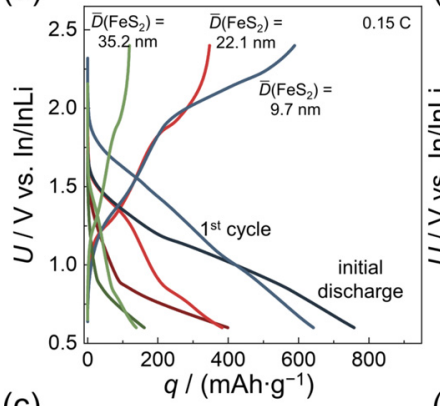

(b)
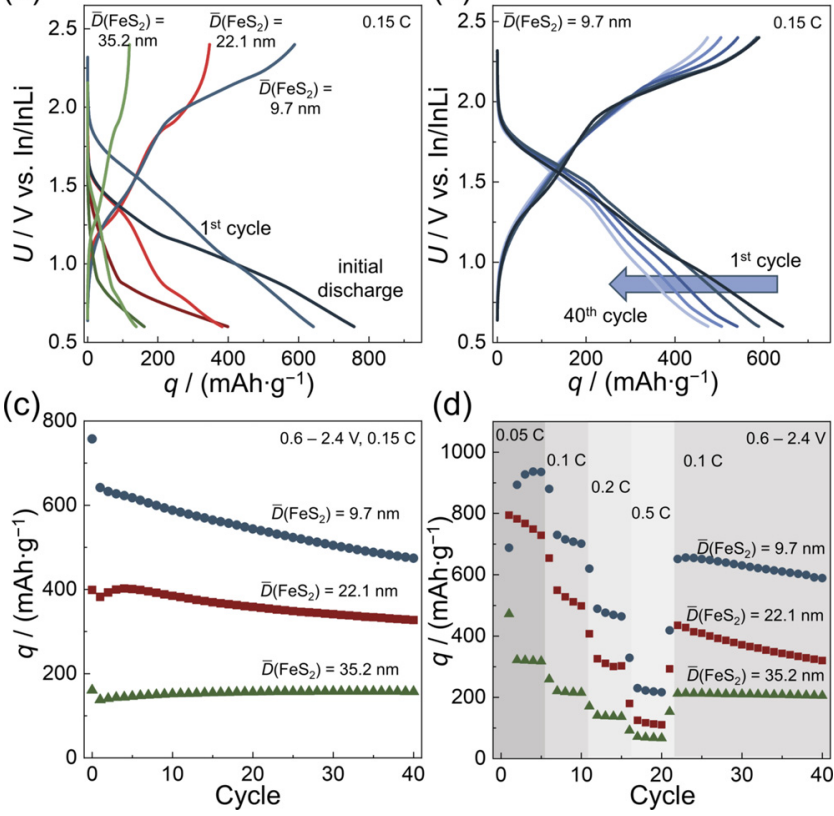

(d)

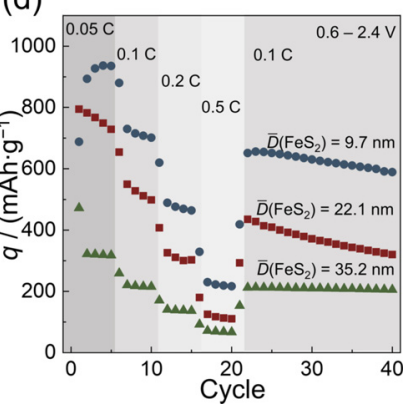

Figure 3. Influence of the $\mathrm{FeS}_{2}$ particle size on performance of In/ $\operatorname{lnLi}\left|\mathrm{Li}_{6} \mathrm{PS}_{5} \mathrm{Cl}\right| \mathrm{FeS}_{2}-\mathrm{C}-\mathrm{Li}_{6} \mathrm{PS}_{5} \mathrm{Cl}$ cells at $25^{\circ} \mathrm{C}$ and an areal $\mathrm{FeS}_{2}$ loading of $3.8 \mathrm{mg} \mathrm{cm}^{-2}$ in the cathode composite. C-rates were calculated based on four electron reductions of $\mathrm{FeS}_{2}\left(0.1 \mathrm{C}=340 \mu \mathrm{Acm}^{-2}\right)$. While similar characteristics regarding the irreversibility of the initial discharge are observed in U-q plots, larger $\mathrm{FeS}_{2}$ particles lead to lower capacities in the initial discharge and following first cycle (a). Despite the irreversible reduction of $\mathrm{FeS}_{2}$ in the initial discharge, long-term cyclization performance suffers only from a gradual capacity fade over 40 cycles, shown exemplary for the cell with an average $\mathrm{FeS}_{2}$ nanoparticle size of $9.7 \mathrm{~nm}$ (b). In direct comparison of long-term cyclization performance, the highest discharge capacities are obtained for a $\mathrm{FeS}_{2}$ particle size of $9.7 \mathrm{~nm}$ (c). A similar trend is found for cyclization at different rates (d). Impedance spectra of the cells shown in (a) and (c) recorded prior to cycling can be found in the Supporting Information. ized post-mortem by X-ray photoelectron spectroscopy (XPS). All the S $2 \mathrm{p}$ and $\mathrm{P} 2 \mathrm{p}$ spectra for the $\mathrm{Li}_{6} \mathrm{PS}_{5} \mathrm{Cl}$ can be found in the Supporting Information. Most likely due to a low overall atomic fraction of $\mathrm{Fe}$ in the investigated cathode composites (approx. 5 at.- $\%$ ), the $\mathrm{Fe}$ spectra cannot be resolved. Figure 4 shows S 2 p detail spectra of the pristine $\mathrm{FeS}_{2}$ particles as well as the cathode composites at different charged and discharged states during cyclization. Besides the expected $\mathrm{S}_{2}{ }^{2-}$ main contribution at around $162.5 \mathrm{eV}$, both reduced and oxidized sulfur species appear. A broad peak $\left(E\left(2 \mathrm{p}_{3 / 2}\right)=163.6 \mathrm{eV}\right)$ can be correlated to the presence of sulfur and long-chain sulfides. Additionally, peaks at higher binding energies (167-169 eV) are found for all samples, which can be assigned to sulfate $\left(\mathrm{SO}_{4}{ }^{2-}\right)$ and sulfite $\left(\mathrm{SO}_{3}{ }^{2-}\right)$ species. ${ }^{[28,29]}$ A reduced species $\left(E\left(2 \mathrm{p}_{3 / 2}\right)=161.4 \mathrm{eV}\right)$ can be attributed to sulfide ions $\left(\mathrm{S}^{2-}\right)$, possibly due to FeS as side product. ${ }^{[22,30]}$ These contributions cannot be fully deconvoluted due to peak overlap. Sulfate and sulfite species have been identified by XPS analyses on solvothermally synthesized $\mathrm{FeS}_{2}$ before and were attributed to surface species. ${ }^{[31]}$ Therefore, these additional phases may just be part of the spectra due to the high surface sensitivity of XPS and the high surface to bulk ratio of the $\mathrm{FeS}_{2}$ nanoparticles. After adding the solid electrolyte $\mathrm{Li}_{6} \mathrm{PS}_{5} \mathrm{Cl}$, the contributions of $\mathrm{FeS}_{2}$ and the solid electrolyte in the resulting cathode composite are strongly convoluted. The S $2 \mathrm{p}$ detail spectrum of pristine $\mathrm{Li}_{6} \mathrm{PS}_{5} \mathrm{Cl}$ shows a main contribution at $161.6 \mathrm{eV}$ of the $\mathrm{PS}_{4}{ }^{3-}$ tetrahedra as well as the free $\mathrm{S}^{2-}$ anion at $160.0 \mathrm{eV}$. While small differences in binding energies impede the resolution of the individual sulfur contributions $\left(\mathrm{S}_{2}{ }^{2-}\right.$ in $\mathrm{FeS}_{2}, \mathrm{~S}^{2-}$ and $\mathrm{PS}_{4}{ }^{3-}$ in $\mathrm{Li}_{6} \mathrm{PS}_{5} \mathrm{Cl}$ ), significant changes in $\mathrm{S} 2 \mathrm{p}$ spectra indicate different sulfur oxidation states in the discharged and charged samples. A clear increase in intensity of the reduced sulfur species $\mathrm{S}^{2-}$ can be found after the initial cell discharge. During the subsequent charge, (partial) re-oxidation shows the contribution of sulfur to the cell capacity as the $\mathrm{S}^{2-}$ signal decreases again. In comparison between cathodes with varied $\mathrm{FeS}_{2}$ particle sizes, less severe changes upon cyclization are observed in the $\mathrm{S} 2 \mathrm{p}$ spectra for larger $\mathrm{FeS}_{2}$ particle sizes (Figure $4 \mathrm{~b}$ ). The lower intensity of the reduction to $\mathrm{S}^{2-}$ for the larger average particle sizes is in accordance with the lower capacity observed during cycling and can be interpreted as hindered active material utilization for larger $\mathrm{FeS}_{2}$ particle sizes.

While the exact deconvolution of contributions here is difficult, due to the superposition of $\mathrm{FeS}_{2}, \mathrm{Li}_{6} \mathrm{PS}_{5} \mathrm{Cl}$ and possible other decomposition products, certain information can be inferred. During the initial discharge, the $\left(\mathrm{S}_{2}\right)^{2-}$ in $\mathrm{FeS}_{2}$ will mostly be reduced to $\mathrm{Fe}^{0}$ and $\mathrm{S}^{2-}$, forming $\mathrm{Li}_{2} \mathrm{~S}$, while reduction of $\mathrm{P}^{5+}$ would result in the decomposition of crystalline $\mathrm{Li}_{6} \mathrm{PS}_{5} \mathrm{Cl}$ as recently observed. ${ }^{[18,27]}$ In the following charge, oxidation of $\mathrm{Li}_{2} \mathrm{~S}$ as well as possible $\mathrm{Fe}$ must be expected to result in the observed multiple redox-active phases. In $\mathrm{Li}-\mathrm{FeS}_{2}$ cells, Fong and Dahn suggested that $\mathrm{FeS}_{2}$, $\mathrm{FeS}_{y}$ and $\mathrm{S}$ are formed during charging. ${ }^{[2]}$ For the oxidative conditions, decomposition of $\mathrm{Li}_{6} \mathrm{PS}_{5} \mathrm{Cl}$ to $\mathrm{S}, \mathrm{P}_{2} \mathrm{~S}_{5}$ and $\mathrm{LiCl}$ was predicted theoretically. ${ }^{[32]}$ However, considering the $\mathrm{P} 2 \mathrm{p}$ spectra of the cycled $\mathrm{FeS}_{2}-\mathrm{Li}_{6} \mathrm{PS}_{5} \mathrm{Cl}-\mathrm{C}$ cathodes, minor changes are found that suggest that the dominant electro- 

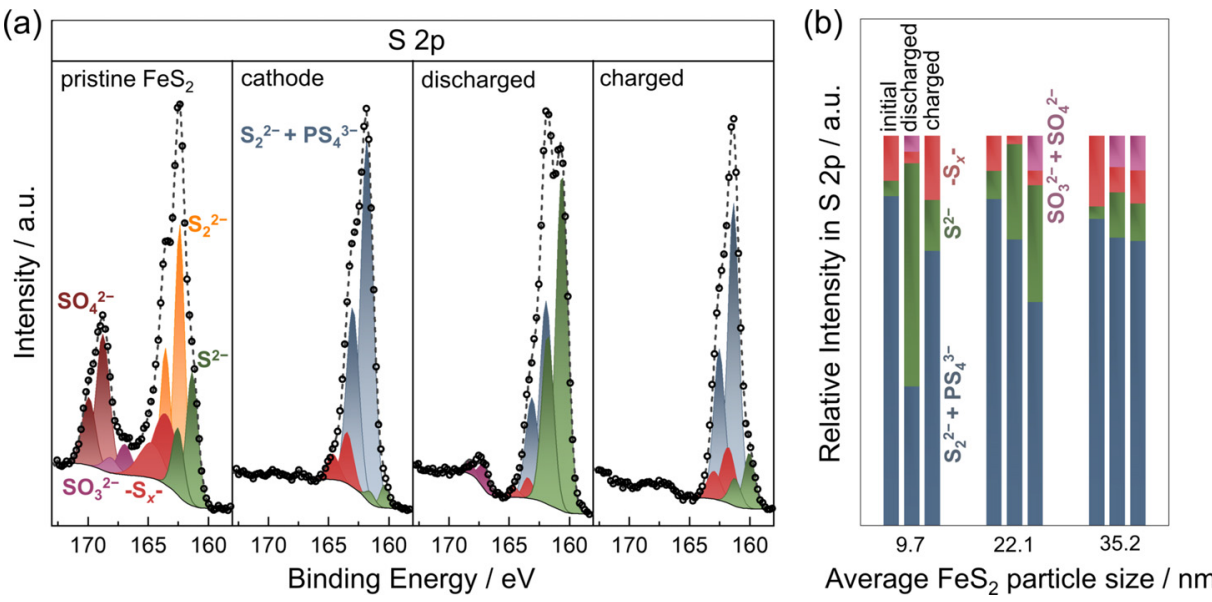

Figure 4. X-ray photoemission sulfur detail spectra of pristine $\mathrm{FeS}_{2}$ nanoparticles (average particle sizes $\bar{D}$ of $9.7 \mathrm{~nm}$ ) and $\mathrm{FeS}_{2}-\mathrm{C}-\mathrm{Li}_{6} \mathrm{PS}_{5} \mathrm{Cl}$ cathodes composites (a). A spectrum with multiple contributions is observed for as-synthesized $\mathrm{FeS}_{2}$ particles. After addition of carbon black and $\mathrm{Li}_{6} \mathrm{PS}_{5} \mathrm{Cl}$, the solid electrolyte and $\mathrm{FeS}_{2}$ contributions to the sulfur signal overlap. An increasing intensity of reduced species indicates sulfur reduction upon cell discharge, reoxidized in the subsequent charge. By visualizing the changes in relative intensity contributions to the $S 2 p$ spectra upon cycling, a clear influence of $\mathrm{FeS}_{2}$ particle size on the extent of sulfur cycling is highlighted (b). Values of relative intensities in S 2p as well as P 2p detail spectra are also shown in the (Supporting Information). This trend can be interpreted as improved sulfur utilization for small $\mathrm{FeS}_{2}$ particle sizes. ticle size distribution of the cathode active materials also matters significantly in conversion-type solid-state batteries.

\section{Acknowledgements}

G.F.D. was supported by the Federal Ministry of Education and Research (BMBF) within the project LISZUBA under grant number 03XP0115A. Z.L. was supported by a fellowship from the German academic exchange program (DAAD). Open access funding enabled and organized by Projekt DEAL.

\section{Conflict of Interest}

The authors declare no conflict of interest.

chemical mechanisms involve the sulfur species. This suggests a degree of oxidative solid electrolyte degradation, ${ }^{[17]}$ which however seems to be independent of particle size and hence surface area of the employed $\mathrm{FeS}_{2}$ particles. Therefore, the more pronounced sulfur redox behavior that can be found when using the smallest sizes $\mathrm{FeS}_{2}$ nanoparticles suggests that more $\mathrm{FeS}_{2}$ is electrochemically addressed and converted (see Figure $4 b$ ).

To exploit the remarkable theoretical capacity of conversion-type electrode materials in competitive solid-state batteries, performance bottlenecks such as low utilization of active materials and poor cycling efficiencies must be overcome. In this work, we used $\mathrm{FeS}_{2}$ as a model-type conversion cathode for solid-state Li-ion storage due to its facile synthesis and high theoretical capacity. $\mathrm{FeS}_{2}$ nanoparticles with three different size distributions were synthesized and characterized. The influence of the size distribution of $\mathrm{FeS}_{2}$ on the solid-state battery performance was evaluated for $\mathrm{In} / \mathrm{InLi}$ $\mathrm{Li}_{6} \mathrm{PS}_{5} \mathrm{Cl} \mid \mathrm{FeS}_{2}-\mathrm{C}-\mathrm{Li}_{6} \mathrm{PS}_{5} \mathrm{Cl}$ cells. A higher capacity and better rate capability were obtained for smaller particle sizes that are unfortunately also accompanied by faster capacity fading. The higher capacity and better rate capability is likely caused by the fact that more active material can be addressed due to the higher surface to volume ratio and the shorter $\mathrm{Li}^{+}$ diffusion pathways inside the $\mathrm{FeS}_{2}$ nanoparticles. Nevertheless, this higher surface to volume ratio provides more interfacial area for competing decomposition reactions and more capacity fading.

Overall, this work highlights the potential of $\mathrm{FeS}_{2}$ as conversion-type cathode material and especially the high relevance of using nanoscale conversion materials in solid state batteries. It further shows that, similar to solid-state batteries with oxide-based cathode active materials, ${ }^{[33]}$ par-
Keywords: conversion electrodes - iron sulfide - nanoparticles . solid-state batteries

[2] Y. Shao-Horn, Q. C. Horn, Electrochim. Acta 2001, 46, 26132621.

[3] J. Xia, J. Jiao, B. Dai, W. Qiu, S. He, W. Qiu, P. Shen, L. Chen, RSC Adv. 2013, 3, 6132-6140.

[4] A. Kraytsberg, Y. Ein-Eli, J. Solid State Electrochem. 2017, 21, 1907-1923.

[5] S.-H. Yu, X. Feng, N. Zhang, J. Seok, H. D. Abruña, Acc. Chem. Res. 2018, 51, 273-281.

[6] A. L. Santhosha, N. Nazer, R. Koerver, S. Randau, F. H. Richter, Adv. Energy Mater. 2020, 10, 2002394.

[7] C. H. Lai, M. Y. Lu, L. J. Chen, J. Mater. Chem. 2012, 22, 19-30.

[8] Y. Lu, L. Yu, X. W. (David) Lou, Chem 2018, 4, 972-996.

[9] T. A. Yersak, H. A. Macpherson, S. C. Kim, V. D. Le, C. S. Kang, S. B. Son, Y. H. Kim, J. E. Trevey, K. H. Oh, C. Stoldt, S. H. Lee, Adv. Energy Mater. 2013, 3, 120-127.

[10] A. Douglas, R. Carter, L. Oakes, K. Share, A. P. Cohn, C. L. Pint, ACS Nano 2015, 9, 11156-11165.

[11] M. Walter, T. Zünd, M. V. Kovalenko, Nanoscale 2015, 7, 9158 9163.

[12] Y. Shao-Horn, S. Osmialowski, Q. C. Horn, J. Electrochem. Soc. 2002, 149, A1499.

[13] D. Zhang, J. P. Tu, J. Y. Xiang, Y. Q. Qiao, X. H. Xia, X. L. Wang, C. D. Gu, Electrochim. Acta 2011, 56, 9980-9985.

[14] S. Qi, L. Mi, K. Song, K. Yang, J. Ma, X. Feng, J. Zhang, W. Chen, J. Phys. Chem. C 2019, 123, 2775-2782.

[15] M. T. McDowell, Z. Lu, K. J. Koski, J. H. Yu, G. Zheng, Y. Cui, Nano Lett. 2015, 15, 1264-1271.

[16] J. Janek, W. G. Zeier, Nat. Energy 2016, 1, 16141.

[17] R. Koerver, F. Walther, I. Aygün, J. Sann, C. Dietrich, W. G. Zeier, J. Janek, J. Mater. Chem. A 2017, 5, 22750-22760.
[1] E. Peled, D. Golodnitsky, E. Strauss, J. Lang, Y. Lavi, Electrochim. Acta 1998, 43, 1593-1599. D. A. Weber, J. Kulisch, T. Adermann, J. Janek, P. Adelhelm, 
[18] T. K. Schwietert, V. A. Arszelewska, C. Wang, C. Yu, A. Vasileiadis, N. J. J. de Klerk, J. Hageman, T. Hupfer, I. Kerkamm, Y. Xu, E. van der Maas, E. M. Kelder, S. Ganapathy, M. Wagemaker, Nat. Mater. 2020, 19, 428-435.

[19] G. F. Dewald, S. Ohno, M. A. Kraft, R. Koerver, P. Till, N. M Vargas-Barbosa, J. Janek, W. G. Zeier, Chem. Mater. 2019, 31 $8328-8337$

[20] G. S. Pawley, J. Appl. Crystallogr. 1981, 14, 357-361.

[21] G. F. Dewald, S. Ohno, J. G. C. Hering, J. Janek, W. G. Zeier, Batteries Supercaps 2021, 4, 183-194.

[22] E. Strauss, D. Golodnitsky, K. Freedman, A. Milner, E. Peled, $J$. Power Sources 2003, 115, 323-331.

[23] S. S. Zhang, D. T. Tran, Electrochim. Acta 2015, 176, 784-789.

[24] R. Fong, J. R. Dahn, J. Electrochem. Soc. 1989, 136, 3206.

[25] U. Ulissi, S. Ito, S. M. Hosseini, A. Varzi, Y. Aihara, S. Passerini, Adv. Energy Mater. 2018, 8, 1801462.

[26] S. Ohno, R. Koerver, G. Dewald, C. Rosenbach, P. Titscher, D. Steckermeier, A. Kwade, J. Janek, W. G. Zeier, Chem. Mater 2019, 31, 2930-2940.

[27] S. Ohno, C. Rosenbach, G. F. Dewald, J. Janek, W. G. Zeier, $A d v$. Funct. Mater. 2021, 31, 2010620.
[28] F. Walther, R. Koerver, T. Fuchs, S. Ohno, J. Sann, M. Rohnke, W. G. Zeier, J. Janek, Chem. Mater. 2019, 31, 3745-3755.

[29] J. Auvergniot, A. Cassel, D. Foix, V. Viallet, V. Seznec, R. Dedryvère, Solid State Ionics 2017, 300, 78-85.

[30] P. Velásquez, D. Leinen, J. Pascual, J. R. Ramos-Barrado, P. Grez, H. Gómez, R. Schrebler, R. Del Río, R. Córdova, J. Phys. Chem. B 2005, 109, 4977-4988.

[31] J. Xia, J. Jiao, B. Dai, W. Qiu, S. He, W. Qiu, P. Shen, L. Chen, RSC Adv. 2013, 3, 6132.

[32] Y. Zhu, X. He, Y. Mo, ACS Appl. Mater. Interfaces 2015, 7, $23685-23693$

[33] E. Trevisanello, R. Ruess, G. Conforto, F. H. Richter, J. Janek, Adv. Energy Mater. 2021, 11, 2003400.

Manuscript received: May 4, 2021

Revised manuscript received: June 15, 2021

Accepted manuscript online: June 15, 2021

Version of record online: July 9, 2021 